\title{
Micro Financial Structure Empowerment of Creative Small and Medium Enterprises (SMEs)
}

\author{
Chairul Furqon, Suryana, Budhi Pamungkas \\ Faculty of Economics and Business Education \\ Universitas Pendidikan Indonesia \\ Bandung, Indonesia \\ c_furqon@upi,edu
}

\begin{abstract}
Creative industry occupies a strategic position in the development of industry in Indonesia today. Its improvement still encounters obstacles, especially with regard to the financial structure. Therefore, this study aimed to gain an overview of the financial structure, and identify factors driving and inhibiting in the development of creative SMEs financial structure based on local raw materials in West Java. The research used qualitative methods, data collected by observations, interviews, and literature study. The results shows that there are still a lot of potentials that could be developed include the potential market is very large, so it is necessary to strengthen the financial structure of micro. So it is expected to improve the competitiveness of SMEs both at home and abroad. There are several constraints faced by developing the strengthening of the financial structure of micro channeled through cooperatives, is generally associated with knowledge about microfinance inadequate. The driving factors in developing microfinance structures associated with the market potential and SMEs are growing in line with the creativity of SMEs especially in the West Java -based local materials through financing undertaken by the cooperative. The overall result showed that the strengthening of the financial structure of micro SMEs based creative local raw materials in West Java can improve competitiveness both domestically and abroad.
\end{abstract}

Keywords- microfinance, micro financial structure, empowerment, small and medium enterprises.

\section{INTRODUCTION}

There is some justification underlying strategic position of the creative industries in the development of industry in Indonesia, namely: (1) Creative industries are able to survive in the midst of the global financial crisis (2) Creative industry sector's contribution to national GDP, and employment tends to rise, and (3) Growing domestic market and the middle class will increase the demand for new goods created from the creative industries. West Java is one of the centers of creative industries in the country. Creative industry's sector accounted for 7.8 per cent of West Java GDP [1]. The contribution increased significantly, in 2003 the amount $12.82 \%$, then rose to $14.46 \%$ or equivalent to 36 trillion Rupiahs (Economic Section of Bandung, 2010). Policy priority in the development of creative industry's creative industries that use local raw materials.

Creative Economy Development Plan 2009-2015 prepared by the Ministry of Industry and Trade in 2008 has 5 development goals, including the importance of the availability and distribution of raw materials that support the growth of the creative industries, and the importance of the industry can be a local identity of the region. Creative industries based on local raw materials are a priority of development. Some literature and the results showed that the industry is not dependent on imported raw materials have a high level of production stability and business continuity are high. The study results also showed that most of the major economic activity of a region is an industry that has the raw materials come from the region itself. The industry is considered to be capable of providing significant economic impact for businesses and the public and relevant stakeholders. Based on consideration of the strategic role of the creative industries based on local raw materials, this study will focus on creative industries based on local raw materials.

However, the development of creative industries in West Java facing some obstacles that can be identified as follows:

- Data mapping business potential and economic value of the creative industries is very little that the development strategy that appears still run independently and does not take priority to the aspects of development that must be done. Bandung regency government policies not involve cross-cutting, including colleges and businesses. Creative industry will always exist because it is part of the culture of West Java community, but will not develop well without any serious policy of the local government. Not all local authorities have a master plan or blueprint for the development of creative industries [1].

- Handicraft industry is small and medium enterprises (SMEs) with limited access, both technological and financial access to the poor quality of the resulting product.

There are advantages of SMEs compared to large enterprises, namely: (1) innovations in technology that have easily happened in product development; (2) based on local resources to utilize the maximum potential and strengthen self-reliance; (3) the ability to create enough employment or absorption of the workforce; (4) flexibility and ability to adapt to changing market conditions faster than large-scale enterprises are generally bureaucratic; $(5)$ the presence of the dynamism of managerial and entrepreneurial roles; (6) is owned and implemented by the local community to develop 
the human resources; (7) dispersed in large numbers so that an equitable development of effective tools [2].

Although it has the potential of so many, the reality shows that SMEs are still not able to realize its full potential capabilities and its role in social and economic function. This is because SMEs however face many barriers and obstacles, both external and internal, in the field of production and processing, marketing, capital, human resources and technology and the business climate are not conducive to development. Under fewer favorable conditions are required an effort to develop SMEs. Attention to develop small and medium enterprises at least based on the number of reasons. One of them is specifically concerned with the financial aspects; the financial structure is characterized using its own capital without any help from the government or private parties in the bulk of SMEs [3].

The capital is issued in private capital and the family capital; this is done in the craft industry entrepreneurs' Bandung Regency to simplify the process of financial management is not too much involved many people. An aspect of profit is also considered good enough indicators that they are able to meet the needs of family life. In the context of business development, of course it is advisable to have the capital resources from the outside (a loan from a bank or cooperative). Most of the craft industry does not want to deal with bank loans. It certainly needs to be disseminated related schemes soft loan scheme that can be used at once necessary assistance in business management. It has become very important for the development of enterprises, sustainability efforts, as well as venture capital security lent.

The strong resilience of Indonesia from the impact of the current crisis is one of them is supported by the SME sector, which is basically the SME sector is a core target rather than the target microfinance. Indonesian microfinance market itself growing very fast; this is because microfinance has an important role in spurring economic growth, both in rural and urban areas. In addition to being a tool to increase the productivity of the economy, microfinance has also become a tool for economic empowerment. This is what should be the concern of government to empower citizens in the economy, by developing microfinance in Indonesia in order to strengthen the resilience of the impact of the current crisis.

The development of microfinance can be a solution to the above problems, because microfinance own target market is a middle-class society in which the business activities are not directly affected by the domino effect of the global economic crisis in many parts of the world today. Small and medium enterprises (SMEs) are the sectors that most benefit from microfinance; this is because the capital needed by SMEs is not large, so it can still be covered by microfinance. SME sector itself is one of the largest contributors to the sector's GDP income countries. In addition to the SMEs sector is also the sector most absorbs labor

In the application of microfinance, government could cooperate with financial institutions that exist, especially the institution of sharia. If not, the government can make its own microfinance programs or institutions that are clear goals and accomplishments. It is now the government has been promoting the financing of the SME sector, but in fact, it has not run optimally. This is what happened this time, the lack of concern of the government against the people of a small trigger.

There are several things that must be done by the government for the empowerment of microfinance to the fullest. Namely, first, the Government published legislation or government regulation that regulates MFIs, and requires each country to set up the MFI. Secondly, guidance and supervision of MFIs conducted by an agency that has the experience to build the MFI. Third, the local government in collaboration with banking institutions for training members on the board of MFIs in the villages. Former research related to microfinance shows that whether a Micro Finance Institution (MFI)'s forprofit status influences its lending decisions toward business start-ups. The findings suggest that the rate of lending to startups is much higher among not-for-profit MFIs compared to for-profit MFIs [4]. The other research indicates that transparency -in all aspects of an MFI's operations - that creates trust between the firm and all of its stakeholders is essential for successful performance [5]. There is a strong relationship between micro entrepreneurship and economic empowerment. Based on these findings it can be suggested that various organizations like MFI involved in microfinance should closely monitor the utilization of credit by their clients and encourage them to use more for productive purposes [6].

Therefore, the general objective of this study is to know how the financial structure of micro (micro financial structure) used in creative SMEs based on local raw materials in western Java in order to improve competitiveness, while the first-year study specifically aims to:

- Obtain an overviews of the financial structure of SMEs creative local raw materials based in West Java.

- Identify driving factors and obstacles in the development of creative SMEs financial structure based on local raw materials in West Java.

\section{LITERATURE REVIEW}

The creative industry is an industry that combines creativity to generate wealth and employment. Product called commercial product, namely creative goods and services. Characteristics of the creative industries are the strategic role of human beings through the creativity, expertise and talent [7]. According to UNESCO, the creative industries are formed by a creative culture, the culture that combines creation, product, and commercialization. Product called commercial product, namely creative goods and services. Creative industry's sector by UNDP and UNCTAD in the Creative Report is composed of: Advertising, Architecture, Art and antiques market, Crafts, Design, Fashion, Film and Video, Music, Performing, arts, Publishing, Software, TV and radio, video and computer [8].

The creative industry is a strategic industry in the economy of Indonesia. According to the Ministry of Trade there are several underlying reasons are: 
- Contribution of creative industries to: (a) the gross domestic product; (b) creating jobs; (c) an increase in exports.

- Creative industries have a social impact, which can improve the quality of life, and increased social tolerance.

- Creative industries to encourage innovation and creativity, which can create: (a) new ideas and, (b) the creation of value.

- With the creative industry of renewable resources, namely due to: (a) based on knowledge, creativity, (b) green community.

- The creative industries can create a business climate, due to: (a) can create a field of business, (b) have implications for other sectors, (c) may expand marketing networks.

- With the creative industries to improve the image and identity of the nation, which can improve: (a) tourism, (b) a national icon, (c) building a culture, cultural heritage, (c) local values [8].

\section{A. Characteristics of Small and Medium Enterprises (SMEs)}

A committee for economic development put forward the concept of small and medium enterprises with more emphasis on the quality rather than quantitative criteria to distinguish the company's small, medium and large. There are four aspects that is used in the SME concept, namely; the first, possession; secondly, the operation is limited to the environment or set of investors; the third area of operations is limited to the surrounding environment, even though marketing can go beyond the local region; fourth, the size of the other companies in the same business line. Size referred to the number of workers or employees or other significant units [9].

\section{B. The role of SMEs for Economic Growth}

In economic development in Indonesia, SMEs are always portrayed as a sector which has an important role because most of the population is poorly educated and live in small business activities of both the traditional and modern sectors. The role of small businesses has become the preferred part in the planning stage -managed by the two departments, namely (1) the Ministry of Industry and Trade; (2) the Ministry of Cooperatives and SMEs. However, the development effort that has been implemented is still not satisfactory result, since the fact that the advancement of SMEs are very small compared with the progress made great efforts. In a macroeconomic analysis of economic growth is defined as growth rates of per capita income. Economic growth is used to describe an economy that has been developed and achieve a higher level of prosperity. Economic growth in a country can be seen from the growth rate of GDP. GDP growth rate which is the rate of output derived from the production function of goods and services. The production function according to Mankiw (2003) is the relationship between the level of output (Y) to the level of inputs (capital and labor). The first derivative of the production function is defined as follows:

$$
\mathrm{Y}=\mathrm{f}(\mathrm{K}, \mathrm{L})
$$

Based on this, the value of GDP is directly influenced by the level of investment which is $\mathrm{K}$ ( capital) and a labor force that is Labor (L) in production function. SME investment each year continues to increase it enhances the efficiency of the economy in the form of capital goods which are very important in economic growth. The role of small and medium enterprises (SMEs) in the Indonesian economy most cannot be seen from: (1) its position as a major player in economic activity in various sectors; (2) the largest provider of employment opportunities; (3) a significant player in the development of local economic activities and community empowerment; (4) The creator of new markets and sources of innovation; and (5) contribution in maintaining the balance of payments through export activities. The role of cooperatives, micro, small and medium very strategic in the national economy, so it needs to be the focus of national economic development in the future [10].

Structured empowerment and sustainable SMEs are expected to be able to harmonize the national economic structure, accelerate national economic growth above 6 percent per year. It also can reduce the level of unemployment, reduce poverty, real sector dynamic, and improve income distribution community. MSME aimed at improving productivity and competitiveness, and systematically directed at efforts to foster new entrepreneurs in sectors which have high productivity based on knowledge, technology and local resources [10].

Economic growth requires support adequate investment. On Indonesia's current economic conditions, relatively difficult to attract investment in large quantities. To that end, the limitations of investment need to be directed at efforts to develop entrepreneurial micro, small and medium enterprises, because it has a lower ICOR with a short time lag. MSME expected to be able stimulated high national economic growth in a relatively short period of time and is able to provide more jobs and more widely, so as to reduce the level of unemployment and poverty in Indonesia[9].

SMEs can improve macroeconomic stability, because the use of local raw materials and export potential, which will help stabilize the exchange rate and the inflation rate. SME will move the real sector, as SMEs generally have a fairly high industrial relevance. In other words, the empowerment of SMEs will give the expansion of employment and income generation in order to support development and economic growth [9].

\section{Micro Financial Structure}

Micro in terms of microfinance is to explain the ' inferiority or limitations, namely the inferiority of the poor that are difficult or limited access to financial services / banking. Some definitions of microfinance are as follows. The Foundation for Development Cooperation: microfinance as the provision of financial services, especially savings and loans for poor households that do not have access to formal financial institutions.

According to the definition used in the Micro Credit Summit, micro credit program is the provision of credit for small amounts to the poorest to finance the project he's 
working on his own in order to generate income, allowing them to care for themselves and their families, "Programs extend small loans to very poor for self-employment projects that generate income, allowing them to care for Themselves and their families " While Bank Indonesia defines micro credit is a credit given to businesses productive both individuals and groups who have the sale of at most one hundred million per year. Financial institutions involved in micro lending are generally referred to Microfinance Institutions (MFIs) [12].

According to the Asian Development Bank (ADB), microfinance institutions is an institution that provides storage services (deposits), loans (loans), payment transactions services (payment services) as well as money transfers targeted to the poor and small businesses (insurance to poor and low - income Households and their microenterprises). While the shape of the MFI can be either: (1) the formal institutions such as banks and rural cooperatives, (2) semiformal institutions e.g. non-governmental organizations, and (3) the resources e.g. informal moneylenders.

While a more detailed definition formulated by Marguerite Robinson in his book is quite phenomenal, The Microfinance Revolution Volume I \& II, "microfinance is small-scale financial services provided to people who farm or fish or herd; who operate small or microenterprises where goods are produced, recycled, repaired, or traded; who provide services; who work for wages or commissions; who gain income from renting out small amounts of land, vehicles, draft animals, or machinery and tools; and to other individuals and groups at the local levels of developing countries, both rural and urban".

From the various terms mentioned above that microfinance contains three main elements that differentiate it from other financial intermediaries such as banks, namely:

- Limitation of the transaction, the transaction value of microfinance is not universal meaning there is no international convention that sets the value of transactions in the category of small or micro. In Indonesia, the transaction value of microfinance is only defined on a micro credit limits only the maximum of 50 million rupiahs. As for other financial transactions such as savings, insurance, remittance, payment systems there is no clear regulation.

- Market Segment, microfinance is unique in serving the community that is focused on the poor, who are divided into four groups:

- Group I which are the poorest of the poor. Poor people who have no source of income due to aging, illness, physical disability that does not have an income.

- Group II is laboring poor. The poor who work as laborers with very limited income and no permanent or seasonal character who generally work in agriculture or other sectors that are labor intensive.

- Group III is a self -employed poor. It is a relatively poor population who earn enough to meet basic living needs by working in the informal sector.
- Group IV is economically active poor. Group that has had economic power with a source of sufficient income to meet basic living needs and have surplus income.

- The purpose, state of practice of microfinance is now inseparable from the history of his birth is to overcome the problems associated with poverty. Further development of microfinance into one agenda to achieve the Millennium Development Goals to reduce world population by half by 2015. It is then amplified by UN Resolution No. A / $58 / 488$ on the International Year of Microcredit 2005 to encourage microfinance as a sector inclusive finance.

Micro banking, microfinance services can be done by governments, individuals, private sector, NGOs, formal or informal financial institutions. Microfinance services performed by banks called micro banking. Micro banking is how banks which are formal financial institutions should be able to serve the micro sector, which is generally informal, or how micro informal sector could be included in the formal banking sector.

\section{RESEARCH METHODS}

The research was carried out in 2015 to 2017. The location and the object of research done on the creative SMEs based raw materials locally in West Java. For the first year, 2015, Qualitative methods used in this research, meanwhile data collected by observations to 20 SMEs, and interviews to 20 informants.

For the second and third year, mix method will applied for the research. By quantitative methods, data used consisted of primary data and secondary data. Primary data collected comes from respondents consisting of creative SMEs based raw materials locally in West Java. The research includes identifying data of respondents, the response of respondents to each activity which is based on creative activities of SMEs based on local raw materials. While the secondary data used relates to the financial structure of the activities undertaken. Data collection instruments used in this study was a questionnaire, which contains questions that are closed related to the application of microfinance in local raw materials based creative SMEs in West Java.

\section{RESEARCH RESULTS}

\section{A. SMEs in West Java Province}

West Java province has natural conditions with a complex geological structure with a mountainous region located in the central and southern part and lowlands in the northern region. Has a forest area with the function of conservation forest, protected forest and production forest proportion reached $22.10 \%$ of the area of West Java; rainfall ranging between $2000-4000 \mathrm{~mm} / \mathrm{yr}$ with high rainfall intensity level; has 40 Watershed (DAS) with a surface water discharge 81 billion $\mathrm{m} 3$ /year and groundwater 150 million $\mathrm{m} 3 / \mathrm{yr}$.

Administratively, West Java region is divided into 27 districts/cities, covering 18 districts, and consists of 626 districts, 641 villages and 5,321 villages. Geographical conditions as it have been mentioned above, causing the 
famous West Java effort agrarian sector. But the development is now the province of West Java to develop all sectors of trade and services. Development of trade and services sectors in the province of West Java, of course, coupled with the potential of raw materials locally owned West Java. West Java now has a lot of potential that can be developed; it is seen from the data center for SMEs in West Java as follows:

TABLE I. SMES CENTERS IN WEST JAVA PROVINCE

\begin{tabular}{|c|c|c|c|}
\hline No & SMEs centers & Location & SMEs number \\
\hline 1 & Batik & Cirebon & 13 \\
\hline 2 & Doll & Bekasi & 12 \\
\hline 3 & Vegetables & Bandung & 13 \\
\hline 4 & Craft & Bandung & 1 \\
\hline 5 & Chocolate \& cake & Bandung & 2 \\
\hline 6 & Leather & Bandung & 1 \\
\hline 7 & Snacks & Cirebon & 6 \\
\hline 8 & Bread & Kuningan & 19 \\
\hline
\end{tabular}

Based on Table I shows that the potential of local raw materials, services, and trade in West Java province is very diverse. It's just that these potentials have not been utilized optimally in counties or cities that are in the province of West Java. Though many centers or industrial areas in West Java Province. Some of it even is a superior product like dodol Garut, Tasik embroidery, tahu Sumedang, and candied Cianjur. The rest is not much to know about other products produced by small and medium industries in the region of West Java.

Many factors cause SMEs in West Java Province is less widely known, one of which is the capital is still limited. As for the development of SME loans in West Java province is as follows:

TABLE II. CREDIT OF SMES IN WEST JAVA BASED ON BUSINESS CLASSIFICATION

\begin{tabular}{|c|c|c|c|}
\hline \multirow{2}{*}{ Business Classification } & \multicolumn{3}{|c|}{ Year (\%) } \\
\cline { 2 - 4 } & $\mathbf{2 0 1 2}$ & $\mathbf{2 0 1 3}$ & $\mathbf{2 0 1 4}$ \\
\hline Medium Credit & 43.12 & 48.93 & 48.17 \\
\hline Small Credit & 34.72 & 28.42 & 29.67 \\
\hline Micro Credit & 22.25 & 21.17 & 22.15 \\
\hline \multicolumn{2}{|c}{ (Source: $\underline{\text { http://www.bi.go.id/, 2015, data reprocessed) }}$}
\end{tabular}

As shown in Table II, the SMEs loans are widely used for medium credit business classification. The medium credits are fluctuated from year to year; in 2014 it decreased compared to 2013. The small credit are in the middle position after the credits and in 2014 improved compared to 2013, although it still only micro credit is still low when compared to the year 2012. Then the lowest SME loans used for qualifying micro enterprises whose value tends to decrease when compared to 2011. This illustrates that SME loans by qualifying efforts tend to decrease. These conditions indicate that the bank is too selective in giving or delivering the financing of SMEs. The dominant use of SME loans used for capital loans labor intensive than investment credit. It can be seen from the table III below:

TABLE III. CREDIT OF SMES IN WESt JAVA BASED ON USAGE TyPE

\begin{tabular}{|c|c|c|c|}
\hline \multirow{2}{*}{ Usage Type } & \multicolumn{3}{|c|}{ Year (\%) } \\
\cline { 2 - 4 } & $\mathbf{2 0 1 2}$ & $\mathbf{2 0 1 3}$ & $\mathbf{2 0 1 4}$ \\
\hline Working capital credit & 77.52 & 74.8 & 73.52 \\
\hline Investment credit & 22.47 & 25.2 & 26.47 \\
\hline \multicolumn{2}{|c}{ (Source: http://www.bi.go.id/, 2015, data reprocessed) }
\end{tabular}

Working capital credit is the most widely used although from year to year tends to be decreased. The opposite occurs in the use of investments credit from year to year tends to be increased. That condition illustrates that more business development when compared with opening a new business area. Slow the growth of new business land because it focuses on developing the business. The condition was also supported by the interviews we did with several microfinance institutions which states that the number of members who apply of funding of microfinance institutions represents the movement slow and even stagnate. A barrier faced by microfinance institutions in channeling funding for SMEs one of which is the knowledge of SMEs regarding microfinance institutions remains low. Still the notion SMEs that consider loans through microfinance institutions is complicated, so in this case the board microfinance institutions make progress SMEs which make loans through microfinance institutions experienced a slow movement.

\section{B. Creative Industry in West Java Provence}

Developing the creative economy is not confined to goods and services, but also on the products of cultural arts and crafts businesses [3]. Products of cultural arts and craft businesses generally use local raw materials so that in addition to creating economic value can also introduce the hallmark of natural and cultural resources of a region. Based on the presentation then there are some efforts made by the West Java provincial government to optimize the potential of natural resources and human resources are owned by the Province of West Java.

According to the Governor of West Java Province, Ahmad Heryawan "West Java also requires a strategy of regional economic development which is more catalysts, namely economic policies that are able to develop and strengthen economic actors region, including sectors that have good prospects in the future as well as resistant to regional and global economic shocks, namely the creative industries based on local resources such as SMEs" [13].

Based on the statement then stand DEKRANASDA used as one of the institutions to encourage SMEs in West Java province based on local raw materials in order to improve the competitiveness of craftsmen in West Java ahead of the AEC (ASEAN Economic Community) in 2015. DEKRANASDA is the abbreviation of Java Provincial Crafts Council West chaired by Netty Heryawan Prasetyani. The data of craftsmen in West Java based on raw materials used are as follows: 
TABle IV. Craftsmen in West Java Provence Based on Product RAW MATERIALS USED

\begin{tabular}{|c|c|c|}
\hline No & Product Raw Materials & $\begin{array}{c}\text { Number of } \\
\text { Craftsmen }\end{array}$ \\
\hline 1 & Woods & 122 \\
\hline 2 & Rattan & 22 \\
\hline 3 & Moslem Cloths \& Batik & 60 \\
\hline 4 & Shellfish and Ceramics & 35 \\
\hline 5 & Metal & 36 \\
\hline 6 & Textiles & 26 \\
\hline 7 & Bamboo / Woven & 25 \\
\hline \multicolumn{2}{|c|}{ TOTAL } \\
\hline \multicolumn{2}{|c|}{ d. (Source: DEKRANASDA West Java Provence - 2015, data reprocessed) }
\end{tabular}

From the Table IV it can be seen that woods-based raw material products is a most used by craftsmen in West Java Provence, while the rattan based materials are the least. The total of SMEs craftsmen is 326 in West Java Provence. Based on the Table 4 above, it can be seen that the potential of the creative industry raw material locally in West Java province has considerable opportunities to further develop.

Still according to the chairman of West Java Province DEKRANASDA Prasetyani said, "DEKRANASDA has made efforts to increase the competitiveness of craftsmen in West Java, namely, by setting four locations creative development of the area, such as Cirebon, Tasikmalaya, Bogor and Bekasi" [14].

The data of craftsmen from DEKRANASDA West Java province based on the location of city / regency in West Java province is as follows:

TABLE V. CRAFTSMEN IN West JAVA PROVENCE BASED ON CITY/DISTRICT

\begin{tabular}{|c|c|c|}
\hline No & City/district & Number of Craftsmen \\
\hline 1 & Kota Bandung & 92 \\
\hline 2 & Kab.Bandung & 25 \\
\hline 3 & Kota Banjar & 4 \\
\hline 4 & Kota Bekasi & 28 \\
\hline 5 & Kab. Bekasi & 14 \\
\hline 6 & Kota Bogor & 14 \\
\hline 7 & Kab. Bogor & 15 \\
\hline 8 & Kota Depok & 5 \\
\hline 9 & Kota Sukabumi & 9 \\
\hline 10 & Kab. Sukabumi & 19 \\
\hline 11 & Kab. Cianjur & 12 \\
\hline 12 & Kota Cirebon & 15 \\
\hline 13 & Kab. Cirebon & 16 \\
\hline 14 & Kab. Majalengka & 7 \\
\hline 15 & Kab. Ciamis & 19 \\
\hline 16 & Kota Tasikmalaya & 1 \\
\hline 17 & Kab. Tasikmalaya & 28 \\
\hline 18 & Kab. Karawang & 7 \\
\hline 19 & Kab. Purwakarta & 11 \\
\hline 20 & Kab. Subang & 10 \\
\hline 21 & Kab. Garut & 22 \\
\hline
\end{tabular}

\begin{tabular}{|c|c|c|}
\hline \multicolumn{2}{|l|}{ (Table V, cont.) } \\
\hline 22 & Kab. Sumedang & 18 \\
\hline 23 & Kota Cimahi & 12 \\
\hline 24 & Kab. Indramayu & 3 \\
\hline 25 & Kab. Kuningan & 2 \\
\hline & Total & 408 \\
\hline
\end{tabular}

(Source: DEKRANASDA West Java Provence - 2015, data reprocessed)

Based on Table $\mathrm{V}$ shows that the highest number of craftsmen in Bandung, this is because the city of Bandung as the capital of West Java province is able to optimize and explore the resources contained therein. Although there is difference in the number of craftsmen based raw material with a number of craftsmen by region, it happens because there are some craftsmen are not recorded into the craftsmen based raw materials.

The development of the creative economy is very dependent on the creative class; namely, scientists, businessmen, and government each choose a role as a creator, innovator, and catalyst [3]. Based on such understanding, it can be said in the West Java Province has formed a good synergy between the creative class. This is evident from the role of the West Java provincial government has established the National Regional Crafts Council (DEKRANASDA) as a forum to develop craft SMEs in West Java Province.

\section{Microfinance Institutions and SMEs in West Java Province}

Bank Indonesia defines micro-credit loans to businesses productive, both individuals and groups that have the sales proceeds exceed one hundred million per year. Financial institutions involved in micro lending are generally referred to Microfinance Institutions (MFIs).

The development of SMEs in West Java is supported also by an idea or condition regarding the position of MFI loans to SMEs. The graph below shows the position of SME loans granted commercial banks based on the scale of business is as follows:

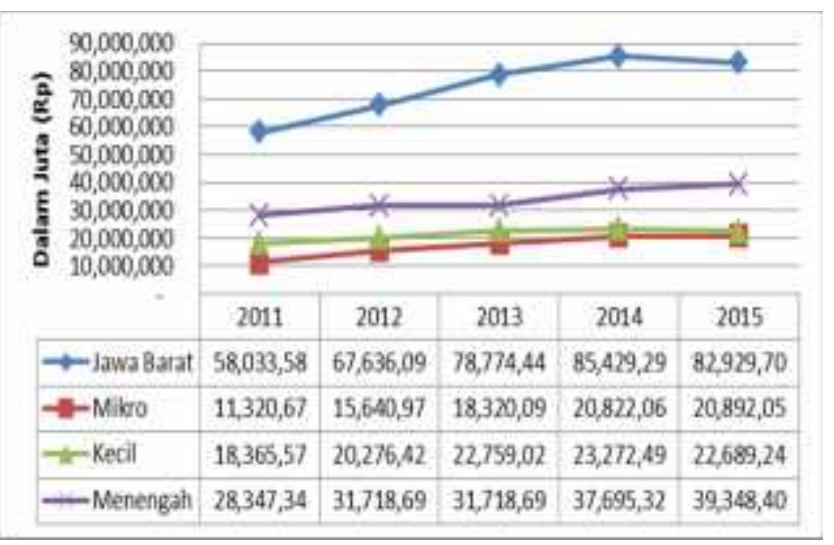

Fig. 1. Credit positions of SMEs given by Commercial Bank based on Business Scale in West Java Provence 
Based on the Figure 1, it shows that the position of the credit for SMEs from year to year tends to increase, conversely in 2015 has decreased. The SMEs credit distribution is given on the smallest scale and medium sized businesses on a scale of micro enterprises. The credit distribution for SMEs from year to year has increased along with the increasing number of SME business units.

Based on these explanations, it can be said that the microfinance institutions is one of the financial limitations solution for SMEs. But it is undeniable that the microfinance institutions has a heavy burden to himself and when dealing with the external environment. Internally, microfinance institutions are also still struggling with problems of management, loan repayment, and others. Externally, must deal with a variety of strengths and interests in order to survive.

About the size of a micro-finance institutions in terms of amount of funds managed, the number of staff, number of clients, and others must be great because the operating costs of a micro-finance institutions is relatively large. While the value of loans and deposits are serviced micro still small, therefore to be able to survive microfinance institutions should have a large range, it means a micro-finance institutions should also be large [2].

It can be said that it is essential to support Microfinance Institutions development activities of SMEs in West Java province, which have benefit that can be felt directly within the scope of micro-economics of the valve defense of national economy.

\section{CONCLUSIONS}

Based on the research that has been done regarding the empowerment model development of creative small and medium enterprises (SMEs) through the micro financial structure strengthening as an efforts to improve competitiveness (studies on local raw materials based creative SMEs in West Java), it can be concluded as follows: a) the results shows that there are still a lot of potential that could be developed include the potential market is very large, so it is necessary to strengthen the financial structure of micro. So it is expected to improve the competitiveness of SMEs both at home and abroad, b) based on the Focus Group Discussion showed that there are several constraints faced by developing the strengthening of the financial structure of micro channeled through cooperatives, is generally associated with knowledge about microfinance inadequate, c) the results also shows that there are driving factors in developing microfinance structures associated with the market potential and SMEs are growing in line with the creativity of SMEs especially in the West Java based local materials through financing undertaken by the cooperative.

\section{ACKNOWLEDGMENT}

We would like to express our deepest gratitude to Bank Indonesia, DEKRANASDA, Small and Medium Enterprises in West Java, who have helped the research from the beginning till its completion.

\section{REFERENCES}

[1] Baskara, I Gde Kajeng. 2013. Lembaga Keuangan Mikro di Indonesia. Jurnal Buletin Studi Ekonomi, Vol. 18, No. 2, Agustus 2013.

[2] Ismawan, Bambang, \& Budiantoro S. 2005. Mapping Microfinance in Indonesia. Jurnal Ekonomi Rakyat. Edisi 22, 2005.

[3] Suryana. 2013. Kewirausahaan: Kiat dan Proses Menuju Sukses. Jakarta, Salemba Empat.

[4] Shahriar, Abu Z.M., Schwarz, S., Newman A. Profit orientation of microfinance institutions and provision of financial capital to business start-ups. International Small Business Journal 2016, Vol. 34(4) 532 552.

[5] Augustine D. Good Practice in Corporate Governance: Transparency, Trust, and Performance in the Microfinance Industry. Business \& Society 51(4) 659-676 (C) 2012 SAGE Publications.

[6] Basargekar P. How Empowering is Micro Entrepreneurship Developed through Microfinance?. Asia-Pacific Business Review Vol. V, No. 1, January - March 2009 pp. 67-76.

[7] Peraturan Presiden Nomor 28 tahun 2008 tentang Kebijakan Industri Nasional (source: http://peraturan.go.id/perpres/nomor-28-tahun-200811e44c4ee60e9b9092e9313231373237.html, accesed on January 2015).

[8] Salim HS, Budi Sutrisno. 2008. Hukum Investasi di Indonesia. Jaccesedakarta, PT Raja Grafinfo Persada.

[9] Wijono, W.W. Pemberdayaan Lembaga Keuangan Mikro Sebagai Salah Satu Pilar Sistem Keuangan Nasional: Upaya Konkrit Memutus Mata Rantai Kemiskinan Kajian Ekonomi dan Keuangan, Edisis Khusus November 2005.

[10] Krisnamurthi, Bayu. Pengembangan Keuangan Mikro dan Penanggulangan Kemiskinan. Jurnal Ekonomi Rakyat, Th. II - No. 2 April 2003.

[11] Robinson, Marguirete. 2000. The Micro Finance Revolution: Sustainable Finance for the Poor. The World Bank.

[12] Micro Credit Summit Report. 1997. United Nation, The World Bank, etc.

[13] Heryawan, A. www.ahmadheryawan.com. accesed on January 2015.

[14] Prasetyani, NH. www.nettyheryawan.com. accesed on January 2015. 